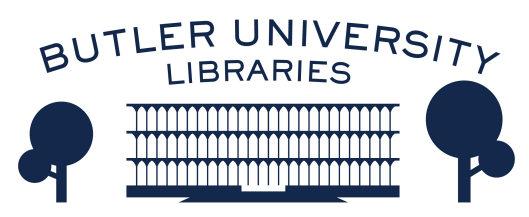

Journal of Hindu-Christian Studies

Volume 11

Article 17

January 1998

\title{
Book Review: "The World's Parliament of Religions: The East-West Encounter, Chicago, 1893"
}

Harold Coward

Follow this and additional works at: https://digitalcommons.butler.edu/jhcs

Part of the Religion Commons

\section{Recommended Citation}

Coward, Harold (1998) "Book Review: "The World's Parliament of Religions: The East-West Encounter, Chicago, 1893"," Journal of Hindu-Christian Studies: Vol. 11, Article 17.

Available at: https://doi.org/10.7825/2164-6279.1190

The Journal of Hindu-Christian Studies is a publication of the Society for Hindu-Christian Studies. The digital version is made available by Digital Commons @ Butler University. For questions about the Journal or the Society, please contact cbauman@butler.edu. For more information about Digital Commons @ Butler University, please contact digitalscholarship@butler.edu. 
a shelter for the hurt and disruption that industrialization brings (p.143). It is in these situations that new Muslim, Hindu, and other identities are created - identities much less tolerant of others and productive of the kinds of psychological projections that foster communal violence and intolerant religious fundamentalism. Kakar concludes, "what we are witnessing today is less the resurgence of religion than (in the felicitous Indian usage) of communalism where a community of believers not only has religious affiliation but also social, economic, and political corresponding interests of another community of believers sharing the same geographical space" (p.147). Many of the same dynamics are explored in literary form in Rohinton Mistry's excellent novel, $A$ Fine Balance.

With population increase and expanding modernization, communal forces encourage psychological projections onto the "other" that foster the kind of violence we see in India, Ireland, or Bosnia. Religious identity can expand one's sense of selfhood so as to create feelings of resonance with other believers, or foster communalism, intolerance, and the potential for social violence when the community believes itself to be threatened. Kakar's book makes a good beginning at uncovering the psychological dynamics at work.

Harold Coward

University of Victoria

\section{The World's Parliament of Religions: The East-West Encounter, Chicago, 1893. Richard H. Seager. Bloomington: Indiana University Press, 1995.}

READING THE PAINSTAKINGLY researched and engrossingly written book on the 1893 World Parliament of Religions in Chicago makes one realize how the recent Centennial Parliament pales by comparison. Seager's careful scholarship convincingly shows that the original parliament marked a point of religious and cultural change in North America. In line with the liberal and evolutionary thinking of the 19th century, the Chicago Parliament set out to unite all religions against irreligion on the ground of Christianity as the superior tradition.

Seager's detailed analysis by text and photograph explores this fascinating event in all its complexity and shows it to be truly a watershed event in the creation of a more pluralistic religious culture in America. With his sustained focus on the East-West encounter, Seager shows how the utopian Judeo-Christian idealism that dominated thinking at the turn of the century was effectively challenged by a small group of Asians. Swami Vivekananda, the BramhoSamaji Majumdar, and the Buddhists Dharmapala of Ceylon, and Shabu Soen of Japan, challenged the naive assumption that the religions of the world could unite in "The Fatherhood of God" and the "Brotherhood of Man". These strangely dressed Eastern leaders demonstrated the real differences in their beliefs that caused the Parliament's attempt to realize the unity of all religions to fail. Both in their presentations at the Parliament and in their lecture tours after the Parliament these Asians exposed the ignorance and imperialism practised by many of the Christian missionaries to Asia, while at the same time demonstrating their own urbane and civilized qualities.

I especially like the author's skilful and 
generous use of the quotations from the speeches given at the event. By reading their actual words we are caught up into the idealism and grandiosity and ethnocentrism of their thought and culture. We see for ourselves that the Parliament failed "because the God of the organizers ... turned out not to be quite the same as the God of the Asians". (p.xxix) In Part One, the context is described in which the Parliament took place - the World Columbian Exposition. Part Two presents the encounter between Eastern and Western religions as it unfolded on the Parliament floor. Part Three examines the responses of the press and representative figures to the events as they unfolded. A fine historian of religion, Seager makes these events come alive in the mind of the reader. Seager takes us back to the glory days of the 1890s when Americans eagerly awaited the coming of the 20th-century global society in which the European JudeoChristian tradition would reign supreme. But he also shows the Parliament pulling Americans up short, making them aware of other religions and opening the door to Eastern missionaries to America (e.g. Vivekananda's Ramakrishna Mission).

Seager concludes that the 1893 World's Parliament was a watershed event, signalling the beginning of the end of Protestant triumphalism in America and offering the start of a new religious pluralism that now, one hundred years later, is just reaching full flower. The Parliament also encouraged its Hindu, Buddhist, and Jaina spokesmen to return home and establish revitalization and modernization movements in their home cultures and religions (e.g. Dharmapala's revival of Buddhism in Ceylon and India).

This book is clearly the classic work on the 1893 Parliament of Religions - one you will want to keep on your bookshelf.

Harold Coward University of Victoria

\section{"The White Woman's Other Burden": Western Women and South Asia during British Rule. Kumari Jayawardena. New York: Routledge, 1995, x + 310 pp.}

THE FIRST THING I had to do was to purchase a new three-way bulb for my lamp so that I was able to read the very fine, closely-typed pages. This, however, is probably the worst criticism I have of this interesting volume. It is a daunting task that the author sets for herself. Beginning from a Universalist perspective on women's subordination, Jayawardena presents a detailed depiction of the roles and activities of foreign women in the context of colonial India with relatively few biases and an impressive attention to detail. In her introduction Jayawardena (p. 4-5) clearly delineates her subject matter:

These were the famous "Women of the Raj": who have been written about extensively and are depicted in literature, films and television serials as brave, long-suffering and strong, or as racist, stupid, and neurotic. What has not emerged, however, was the reality of the colonial wife, living in a sort of doubly refined bondage-isolated in the home as woman and alienated in the colony as a foreigner. This book does not deal with them.

It does deal, however, with other categories of women who had different perceptions of the East. [these] white women had their origins in the reality of the "new woman" who was asserting herself on all fronts. Women all over the world had made one of the most remarkable "leaps" in history in the late 